\title{
Assessment of the Combined Effects of Acetamiprid and Propineb in Vivo
}

\author{
Pınar GÖÇ RASGELE
}

\begin{abstract}
Pesticides are among commonly used chemicals in agriculture and are one of major environmental pollutants. Acetamiprid and Propineb are widely used to control sucking insects and fungal infections on crops, respectively. The study presented aimed to research genotoxic effects of mixture of Acetamiprid and Propineb, in vivo. It was observed that mixture of Acetamiprid+Propineb increases the frequency of micronucleated polychromatic erythrocytes (MNPCE) at all concentrations for 24 and $48 \mathrm{~h}$ depending on concentrations. But these increases were not significant. The combined effect of the Acetamiprid and Propineb on bone marrow cells of mice in vivo was found to be antagonistic in terms of percentage of MNPCE. In addition, mixture of Acetamiprid and Propineb significantly decreased polychromatic erythrocytes/normochromatic erythrocytes (PCE/NCE) ratio at all concentrations. The results of the present investigation revealed that Acetamiprid was non-genotoxic, while mixture of the Acetamiprid and Propineb may have cytotoxic effects for mice bone marrow cells. But, additional in vivo and in vitro mutagenicity studies measuring different levels of DNA damage are still necessary.
\end{abstract}

Keywords: Mice bone marrow, micronucleus assay, mutagenicity, pesticide mixture

\section{Acetamiprid ve Propinebin Kombine Etkilerinin in Vivo Değerlendirilmesi}

ÖZET: Pestisitler tarımda yaygın olarak kullanılan kimyasallardır ve önemli çevre kirleticilerindendirler. Acetamiprid ve Propineb ürünlerde görülen fungal hastalıkları ve entomolojik patojenleri kontrol etmek için yaygın olarak kullanılırlar. Bu çalışmada Acetamiprid ve Propineb pestisit karışımlarının genotoksik etkilerinin in vivo araştırılması amaçlanmıştır. Acetamiprid+Propineb karışımının tüm konsantrasyonlarının 24 ve 48 saatlik muamelelerde konsantrasyonlara bağlı olarak mikronukleuslu polikromatik eritrosit (MNPCE) frekansını arttırdığ 1 gözlendi. Fakat bu artışlar anlamlı bulunmamışlardır. Acetamiprid ve Propineb'in fare kemik iliği hücreleri üzerine olan kombine etkisinin MNPCE yüzdesi bakımından antagonistik olduğu bulunmuştur. Ayrıca, Acetamiprid ve Propineb karışımı polikromatik eritrosit/normokromatik eritrosit (PCE/NCE) oranını tüm konsantrasyonlarda anlamlı olarak azaltmıştır. Çalışmanın sonuçları Acetamiprid'in non-genotoksik olduğunu, Acetamiprid ve Propineb karışımının fare kemik iliği hücreleri için sitotoksik etkilere sahip olabileceğini göstermiş̧ir. Fakat DNA hasarının farklı seviyelerini ölçen ilave in vivo ve in vitro mutajenite çalışmaları yapılması gereklidir.

Anahtar Kelimeler: Fare kemik iliği, mikronukleus yöntemi, mutajenite, pestisit karışımı

Düzce Üniversitesi, Ziraat ve Doğa Bilimleri Fakültesi, Biyosistem Mühendisliği Bölümü, Düzce, Türkiye

${ }^{\mathrm{e} S}$ Sorumlu yazar/Corresponding Author: Pınar GÖÇ RASGELE, pinargocrasgele@gmail.com 


\section{INTRODUCTION}

Pesticides have remained to be threat to the human, environment and other organisms for many years due to their bioaccumulations and persistence in the ecosystems. As much as 4.6 million tons of pesticides are released annually into the environment and this situation becomes a serious health concern, which has resulted in the adverse effects for all living creatures and environment (Zhang et al., 2011). Occupationally or incidentally, all living organisms are exposed to most of chemicals such as pesticides, their mixtures, and harmful gases in the air. The undesired effects of pesticides such as genotoxic, cytotoxic and carcinogenic have been showed (Costa et al., 2006; Pandey, 2008; Blair and Freeman, 2009; Kaymak and Rasgele, 2009; Kumar, 2010; Muranli and Guner, 2011).

Many investigations have been carried out on the genotoxic effects of individual pesticides (Giri et al., 2002; Rasgele and Kaymak, 2006; Kocaman and Topaktas, 2007; Costa et al., 2009; Kocaman et al., 2012; Srivastava et al., 2012). In addition, it is well known that the different effects such as additive, synergistic or antagonistic ones can be observed in the pesticide mixtures (Amorim et al., 2012; Schnug et al., 2014; Shaik et al., 2016; Taillebois and Thany, 2016). Therefore, the determination of genotoxic effects of pesticides mixtures as well as individual pesticides by using different organisms is crucial in environmental studies and combined effects of them should be considered to evaluate the genetic risk.

Acetamiprid (N-[(6-chloro-3-pyridyl) methyl]-N'cyano-N-methyl-acetamidine) is a neonicotinoid insecticide and is used to control sucking insects on crops. Neonicotinoid insecticides are crucially potent neurotoxic insecticides that act as agonists on the nicotinic acetylcholine receptors (Tomizawa and Yamamoto, 1993). Although classified as an "unlikely" carcinogen for human, it has been reported to be clastogen in Chinese hamster ovary (CHO) cells (EPA, 2002). Furthermore, Kocaman and Topaktas (2007) have reported that Acetamiprid induced chromosome aberration (CA), sister chromatid exchange (SCE) and micronucleus (MN) formation in human peripheral lymphocytes. Propineb (Polymeric zinc 1,2-propylenebis (dithiocarbamate), belongs to the dithiocarbamate group of fungicides, is used as an effective agent in the control of plant diseases in a wide range of crops in agriculture (Soloneski et al., 2003). There are many negative results on the effects of Propineb in various test systems such as in Ames test with Salmonella typhimurium, in unscheduled DNA synthesis (UDS) test with rat hepatocytes, in the Hypoxanthineguanine phosphoribosyltransferase (HGPRT) test with $\mathrm{CHO}$ cells, and in dominant lethal mutation test with mice (Watson, 1993). Furthermore, Rolandi et al. (1984) reported that it was observed no statistically significant increase in the frequency of micronuclei at any of tested doses of Propineb. Although classified as an "unlikely" acute hazard in normal use by World Health Organization, Propineb has moderate to low acute toxicity in mice, rats, hamsters, cats and sheep (Watson, 1993). It was observed that many pesticides in which propineb is implicit cause a significant increase in CA and $\mathrm{MN}$ frequencies of many people who use pesticides in agricultural areas (Bolognesi et al., 1993; Pasquini et al., 1996; Falck et al., 1999; Pastor et al., 2001; Pazy-Mino et al., 2002). In our earlier publication (Rasgele et al., 2014), it was showed in mice that Propineb induced significantly formation of micronucleus at 25 and $50 \mu \mathrm{g}$ $\mathrm{mL}^{-1}$ concentrations for $24 \mathrm{~h}$ and at the highest $(50 \mu \mathrm{g} \mathrm{mL}$ $\left.{ }^{1}\right)$ concentration for $48 \mathrm{~h}$. Moreover, significant decline for $\mathrm{PCE} / \mathrm{NCE}$ ratio was obtained at the same concentrations for 24 and $48 \mathrm{~h}$. Numerous genotoxicity markers such as gene mutation assay, chromosome aberration assay and DNA damage assay have been developed for the detection of early biological effects induced by pesticides (Sato and Tomita, 2001). Micronucleus (MN) assay is a tool of great interest in toxicity risk assessment due to its simplicity, accuracy, wide tissue applicability and has been recently used for identification of genotoxic effects (Heddle, 1973; Schmid, 1975; Decordier and Kirsch-Volders, 2006). An increase in the frequency of MNPCE and a decrease in PCE/NCE ratio in treated animals determine genotoxicity and cytotoxicity, respectively (Heddle, 1973).

Acetamiprid and Propineb are commonly used on agricultural crops such as tomato, potato, melon, apple, tobacco, either separately or in combination (Karaca et al., 2009). But, there are a few studies on the genotoxicity of Acetamiprid and Propineb (Rolandi et al. 1984; Barrera et al., 2008; Kocaman and Topaktas, 2010; Cavas et al., 2012), there is no available investigation about mutagenicity of mixtures of Acetamiprid and Propineb in vivo in bone marrow cells of Mus musculus. The aim of this study was to investigate the frequencies of micronucleated erythrocytes following exposure mixtures of Acetamiprid and Propineb in bone marrows cells of mice using micronucleus assay due to commonly use of these pesticides and lack of information about their genotoxicities in vivo. Although we have published our results related to effect of Propineb (Rasgele et al., 2014), the data from that publication will be used to be able to make clear explanations and discussions in this paper because pesticide mixture we used has Propineb.

\section{MATERIAL AND METHODS}

Chemicals: In this study, the trading formula of Acetamiprid (containing $20 \%$ as active agent; CAS No. 135410-20-7) and Propineb (containing $70 \%$ as 
active agent; CAS No. 12071-83-9) were used as the test materials. The commercial formulations of Acetamiprid and Propineb were purchased from Safa Agriculture and Bayer from Turkey, respectively. The chemical structures of Acetamiprid and Propineb are shown in Figures 1 and 2. Giemsa (CAS No. 51811-82-6) and May Grunwald (CAS No.17372-87-1) was obtained from Merck ${ }^{\circledR}$. Mitomycin C (MMC; CAS No. 50-07-7) was used as the positive control while distilled water was used as the negative control. All test solutions were prepared just before each experiment.

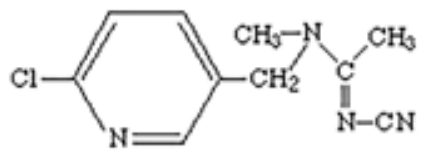

Figure 1. Chemical structure of acetamiprid

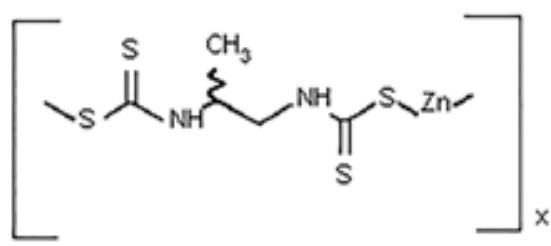

Figure 2. Chemical structure of propineb

Selection of Concentrations: The concentrations used were selected according to the results of a preliminary study. In the preliminary study, the concentrations were selected on the basis of doses used against diseases on crops such as tomato, potato, melon, apple, and tobacco (Karaca et al., 2009). The concentrations of mixtures of Acetamiprid and Propineb that were dissolved in water $(0.625+12.5 ; 1.25+25 ; 2.5+50 ; 5+100 ; 10+200)$ $\mu \mathrm{g} \mathrm{mL} \mathrm{mL}^{-1}$ were used. In the preliminary study, it was observed that the mixtures of Acetamiprid and Propineb exhibited high cytotoxic effects in their two highest concentrations $(5+100 ; 10+200) \mu \mathrm{g} \mathrm{mL}^{-1}$ and decreased the ratio of dividing cells at these concentrations in $48 \mathrm{~h}$ treatment period. Based on the cytotoxicity of the test chemicals, the first three concentrations $(0.625+12.5$; $1.25+25 ; 2.5+50) \mu \mathrm{g} \mathrm{mL}^{-1}$ were determined as the concentrations to be tested in this study. In addition, pesticides were also tested separately in order to determine whether these pesticides would become effective or not when they are alone.

Experimental Animals: Experiments were performed on 8-10 week old male Mus musculus obtained from Abant Izzet Baysal University Experimental Animals Applications and Research Center, Turkey. Mice kept in polyethylene boxes, in controlled environment of temperature, humidity and light provided by the Abant Izeet Baysal Center where experiments were carried out. The experiment was approved by the Ethics Committee of Abant Izzet Baysal University in Turkey.

Fifteen groups were set with 180 mice were randomly allocated. Each group had 12 mice which half of them kept treated 24 hours the other half 48 hours. The groups were as follows:

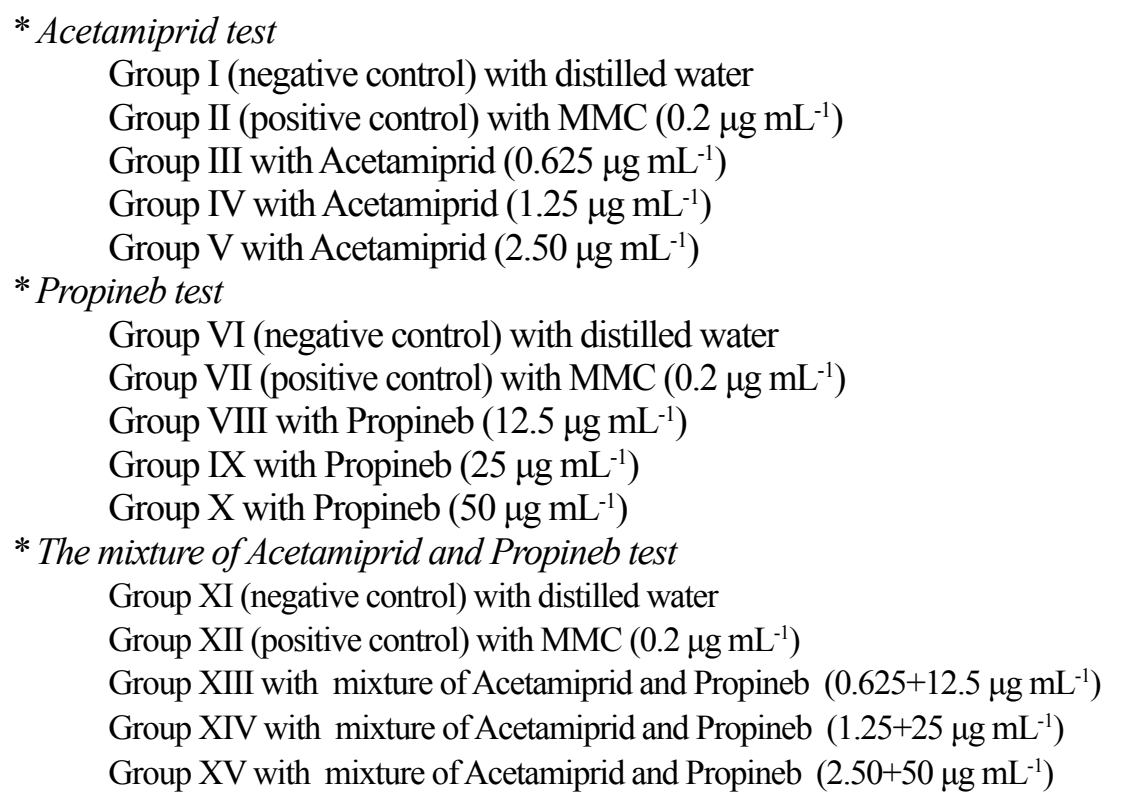

Micronucleus (MN) Assay: Acetamiprid at concentrations of $(0.625,1.25$ and 2.50$) \mu \mathrm{g} \mathrm{mL}^{-1}$ and and Propineb at c oncentrations of $(12.5,25$ and 50$) \mu \mathrm{g} \mathrm{mL}^{-1}$ was given by i.p. route a single injection $(0.01 \mathrm{~mL}$ per gram of animal) for 24 and $48 \mathrm{~h}$. In addition, their mixture was administrated at the same test concentrations over the 
same period. Slides were prepared by the method described by Schmid (1975) and Aaron et al. (1989) with minor revisions as shown below. The cells were removed from bone marrow with fetal calf serum, and the homogenate was centrifuged for $10 \mathrm{~min}$ at $2000 \mathrm{rpm}$. The pellets were resuspended in a drop of serum, plastered it on a slide glass, fixed with methanol and stained with May Grunwald for 3 min, May Grunwald:distilled water (1:1) for $2 \mathrm{~min}, 10 \%$ Giemsa in Sorensen buffer for $10 \mathrm{~min}$ (Rasgele et al., 2014).

Measurement of Micronucleus and PCE/NCE: A total of 2000 erythrocytes were scored for each animal at a magnification of $x 1000$. The numbers of MNPCE and MNNCE were counted. PCE/NCE ratio was calculated.

Statistical Analysis: The data were analysed by using SPSS 20 for Windows and results obtained were expressed as mean \pm SE. The Kruskal-Wallis test was performed

\author{
Measured values $>$ Expected values (insignificantly) \\ Measured values $>$ Expected values (significantly) \\ Measured values $<$ Expected values (significantly)
}

followed by the Mann-Whitney U test to compare the statistical significance of the differences between treated and control groups.

Exposure-response relationship was identified using Pearson correlation analysis. $\mathrm{P}<0.05$ was considered as the level of significance. Measured values were compared with expected values. The expected mean value and SE were calculated as following (Klaric et al., 2008). Mean $\%$ (expected for Acetamiprid+Propineb) $=$ mean \% (Acetamiprid) + mean \% (Propineb) - 100\% (control)

$\mathrm{SE}$ (expected for Acetamiprid + Propineb) $=[(\mathrm{SE}$ for Acetamiprid $\left.)^{2}+(\mathrm{SE} \text { for Propineb })^{2}\right]^{1 / 2}$

The non-parametric Mann Whitney U test was used to detect significance of difference between expected and measured values. Additive, synergistic and antagonistic effects were evaluated to interpret effects of mixtures.

$\begin{array}{ll}\rightarrow & \text { Additive effect } \\ \rightarrow & \text { Synergistic effect } \\ \rightarrow & \text { Antagonistic effect }\end{array}$

of Acetamiprid and Propineb showed a significant synergistic effect at the all concentrations and treatment times due to reduction of PCE/NCE ratio compared to negative control (Table 1).

The data were underwent to linear regression analysis which fit well to define the exposure-response for 24 and $48 \mathrm{~h}$. Acetamiprid, Propineb and mixture of them caused a significant dose-dependent decrease of the PCE/NCE ratio for 24 and $48 \mathrm{~h}$ (Figure 3).

In order to detect the combined actions such as additive, and antagonistic of compounds, the expected mean value and SE were calculated and measured values were compared to expected values (Klaric et al., 2008). The measured \% MNPCE was significantly below the expected values, that is, antagonistic effect was observed at all concentrations of mixture for 24 and $48 \mathrm{~h}$ treatments (Figure 4). The measured \% PCE/NCE ratio was significantly below the measured values, that is, synergistic effect was observed at all concentrations of mixture for 24 and $48 \mathrm{~h}$ treatments (Table 1).

The study presents the first in vivo evidence for the genotoxicity of mixtures of Acetamiprid and Propineb in bone marrow cells of mice. The results of the present study revealed that mixture of Acetamiprid+Propineb increase the frequency of MNPCE at all concentrations for 24 and $48 \mathrm{~h}$ depending on concentrations. But these increases were not significant. 


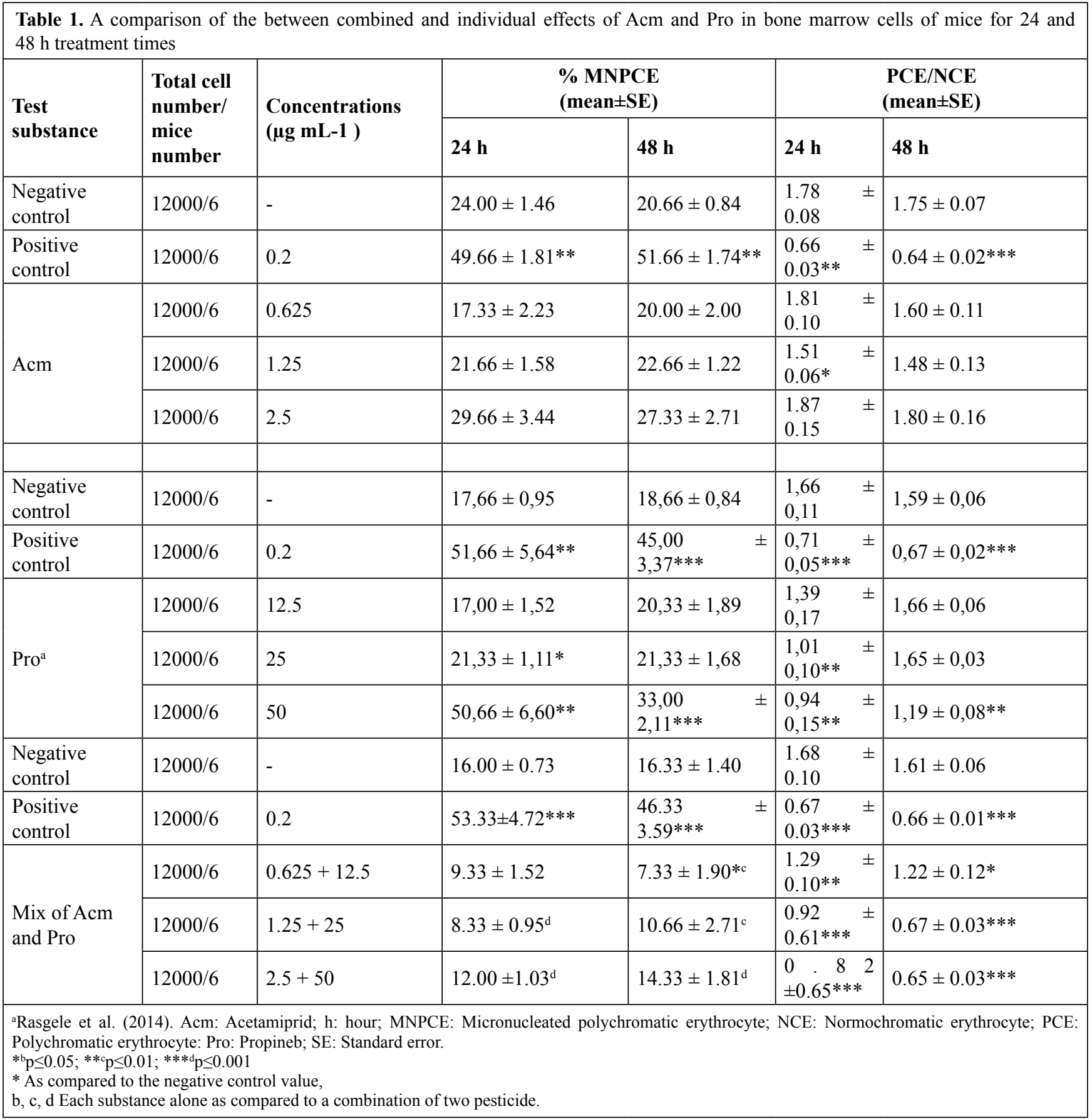

There are many studies on pesticide mixtures' poisoning because of occupational and environmental reasons; but, no available investigation about genotoxicity of mixtures of Acetamiprid and Propineb in vivo in bone marrow cells of mice had not been found in the literature. The mixture of Acetamiprid and Propineb showed antagonistic action in bone marrow cells of mice. Our results were in parallel with the reports of Santamaria et al., (1997) and Piatti et al., (1994), which mixture of different insecticides and fungicides showed antagonistic effect. In the contrary many researches have been reported that the combinations of pesticide showed synergistic effect in bone marrow cells of mice (Meisner et al., 1992; Chauhan et al., 2005; Karabay and Oguz, 2005; Demsia et al., 2007; Sekeroglu et al., 2013) and human peripheral blood lymphocytes (Dolara et al., 1992; Roloff et al., 1992; Das et al., 2007; Demsia et al., 2007; Kocaman and Topaktas, 2010; Muranli et al., 2015). The differences of chemical structure of pesticides and different test systems used in these investigations may be responsible for the different genotoxic results of pesticide mixtures. 

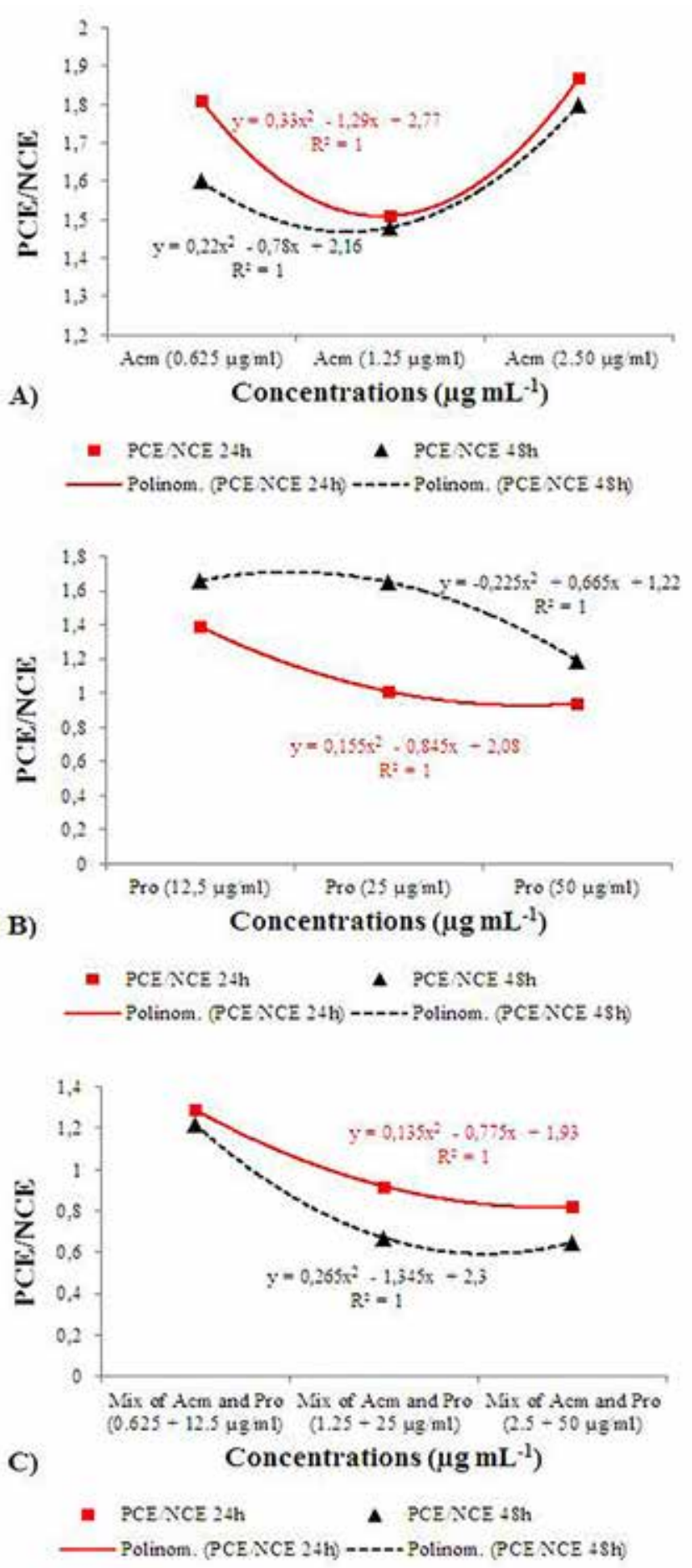

Figure 3. Dose related decrease of PCE/NCE ratio after exposure of Acetamiprid, Propineb and mixture of them for 24 and $48 \mathrm{~h}$.

Propineb individually showed genotoxic effect in mice bone marrow cells (Rasgele 2014); but, Acetamiprid did not show any genotoxic affect. It can be found similar results in earlier literature (Rasgele et al., 2014). These findings could be attributed to different mechanisms involved pesticide action and chemistry.

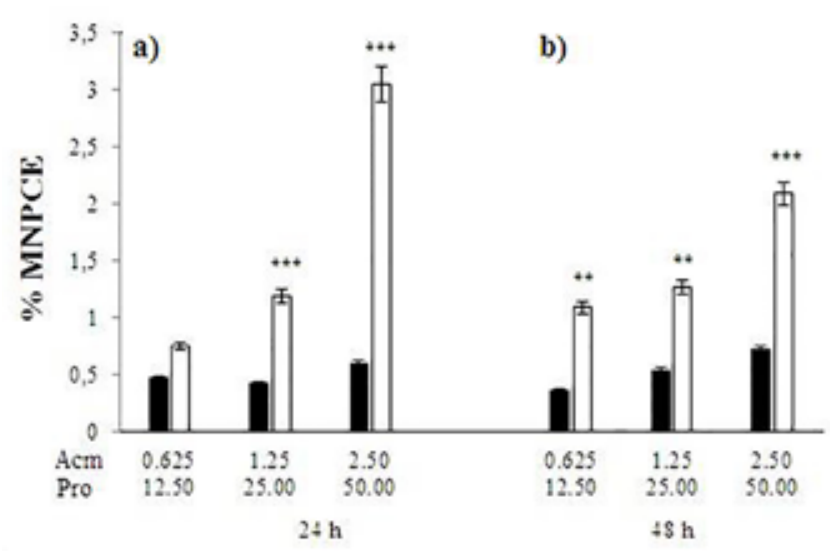

Figure 4. Percentage of micronucleated polychromatic erythrocytes (MNPCE) (Mean \pm S.E.) in bone marrow cells of mice exposed to mixtures of Acetamiprid and propineb (Propineb ) for 24 (a) and $48 \mathrm{~h}$ (b). Dark and white bars represent the measured values and the expected values, respectively. ${ }^{* *}$ and ${ }^{* * *}$ represent significant antagonistic effects, respectively $(\mathrm{P}<0.05)$

The mechanisms of genotoxicity of Acetamiprid and Propineb are not yet known. It was reported that Acetamiprid induced reactive oxygen species (ROS) generation in three bacteria species (Yao et al., 2006) and plants (Ford et al., 2011). Moreover, Jie et al., (2003) have indicated that Acetamiprid might interact with DNA through a non-intercalative way. Guven et al. (1998) have reported that Propineb, as all dithiocarbamates, interferes with the synthesis and metabolism of proteins, due to its isocyanic metabolites and so these intermediates cause the activation/inactivation of sulphidril groups (-SH) present in aminoacids, proteins and enzymes (Lages et al., 2009). In addition, Rath et al., (2011) have noticed that the dithiocarbamate anions are highly reactive which can conjugate with other molecules containing SH groups and form metal chelates. The multisite interactions of dithiocarbamate give them advantage to influence the biological activities of different proteins, enzymes, and exert toxic effects. However, it is also known that the effects of mixtures of pesticide may differ from the individual effects of each pesticide (Marinovich et al., 1996).

\section{CONCLUSIONS}

The combined effect of the Acetamiprid and Propineb on bone marrow cells of mice in vivo was found non genotoxic in spite of genotoxic effect of Probineb alone. But, Acetamiprid and Propineb pesticides have cytotoxic effect when used in combination. Mixtures studies are very important to evaluate exposure to these compounds. 
Occupational and environmental pesticide intoxication have threatened both public and environment health because of their excessive and unconscious uses. For this reason, it should be necessary to be careful when using these chemicals in agricultural areas and should take precautions.

\section{ACKNOWLEDGMENT}

This study was a part of scientific research titled "Micronucleus induction in mice bone marrow and human lymphocytes after exposure to mixture of pesticides acetamiprid-propineb" and it was supported by Duzce University Scientific Research Fund [Project Number = 2011.05.01.070]. The author thanks Fulya Dilek Gokalp and Meral Kekecoglu for supports.

\section{REFERENCES}

Aaron CS, Sorg R, Zimmer D, 1989. The mouse bone marrow micronucleus test: evaluation of 21 drug candidates. Mutation Research, 223(2): 129-140.

Amorim MJB, Pereira C, Menezes-Oliveira VB, Campos B, Soares AMVM, Loureiro S, 2012. Assessing single and joint effects of chemicals on the survival and reproduction of Folsomia candida (Collembola) in soil. Environmental Pollution, 160: 145- 152.

Barrera CH, Pardo LC, Cortina GD, 2008. Antracol WP 70 genotoxicity in human lymphocyte cultures. Colombia Médica, 39: 29-34.

Bianchi-Santamaria A, Gobbi M, Cembran M, Arnaboldi A, 1997. Human lymphocyte micronucleus genotoxicity test with mixtures of phytochemicals in environmental concentrations. Mutation Research, 388(1): 27-32.

Blair A, Freeman LB, 2009. Epidemiologic studies in agricultural populations: observations and future directions. Journal of Agromedicine. 14(2): 125-131.

Bolognesi C, Parrini M, Merlo F, Bonass1 S, 1993. Frequency of micronuclei in lymphocytes from a group of floriculturists exposed to pesticides. Journal of Toxicological Environmental Health, 40: 405-411.

Chauhan LKS, Chandra S, Saxena PN, Gupta SK, 2005. In vivo cytogenetic effects of a commercially formulated mixture of cypermethrin and quinalphos in mice. Mutation Research, 587(1): 120-125.

Costa C, Teixeira JP, Silva S, Roma-Torres J, Coelho P, Gaspar J, Mayan O, 2006. Cytogenetic and molecular biomonitoring of a Portuguese population exposed to pesticides. Mutagenesis, 21(5): 343-350.

Costa C, Silvari V, Melchini A, Catania S, Heffron JJ, Trovato A, De Pasquale R, 2009. Genotoxicity of imidacloprid in relation to metabolic activation and composition of the commercial product. Mutation Research, 672(1): 40-44.

Cavas T, Cinkilic N, Vatan O, Yılmaz D, Coșkun M, 2012. In vitro genotoxicity evaluation of acetamiprid in $\mathrm{CaCo}-2$ cells using the micronucleus, comet and $\gamma \mathrm{H} 2 \mathrm{AX}$ foci assays. Pesticide Biochemistry and Physiology, 104(3): 212-217.
Das PP, Shaik AP, Jamil K, 2007. Genotoxicity induced by pesticide mixtures: in-vitro studies on human peripheral blood lymphocytes. Toxicology and Industrial Health, 23(8): 449-458.

Decordier I, Kirsch-Volders M, 2006. The in vitro micronucleus test: from past to future. Mutation Research, 607: 2-4.

Demsia G, Vlastos D, Goumenou M, Matthopoulos DP, 2007. Assessment of the genotoxicity of imidacloprid and metalaxyl in cultured human lymphocytes and rat bone-marrow. Mutation Research, 634(1): 32-39.

Dolara P, Salvadori M, Capobianco T, Torricelli F, 1992. Sisterchromatid exchanges in human lymphocytes induced by dimethoate, omethoate, deltamethrin, benomyl and their mixture. Mutation Research Letters, 283(2): 113-118.

EPA, 2002. United States Office of Prevention, Pesticides Environmental Protection and Toxic Substances Agency (7501C) Pesticide Fact Sheet Name of Chemical: Acetamiprid Reason for Issuance: Conditional Registration Date Issued. https://www3. epa.gov/pesticides/chem_search/reg_actions/registration/fs_PC099050_15-Mar-02.pdf (Erişim tarihi: 04 Nisan 2016).

Falck GCM, Hirvonen A, Scarpato R, Saarikoski ST, Migliore L, Norppa H, 1999. Micronuclei in blood lymphocytes and genetic polymorphism for GSTM1, GSTT1 and NAT2 in pesticideexposed greenhouse workers. Mutation Research, 441(2): 225237.

Kaymak F, Rasgele PG, 2009. Genotoxic Effects of Raxil on Root Tips and Anthers of Allium cepa L. Caryologia, 62(1): 1-9.

Ford KA, Gulevich AG, Swenson TL, Casida JE, 2011. Neonicotinoid insecticides: oxidative stress in planta and metallo-oxidase inhibition. Journal of Agricultural and Food Chemistry, 59(9): 4860-4867.

Giri S, Prasad SB, Giri A, Sharma GD, 2002. Genotoxic effects of malathion: an organophosphorus insecticide, using three mammalian bioassays in vivo. Mutation Research, 514(1): 223231.

Guven K, Deveci E, Akba O, Onen A, De Pomerai D, 1998. The accumulation and histological effects of organometallic fungicides Propineb and Maneb in the kidneys of fetus and female rats during pregnancy. Toxicology Letters, 99(2): 91-98.

Heddle JA, 1973. A rapid in vivo test for chromosomal damage. Mutat. Res., 18: 187-190.

Jie N, Hou S, Du F, Huang L, Jiang G, Lv S, 2003. Study on the interaction between nucleic acids and acetamiprid. Nucleosides, Nucleotides and Nucleic Acid, 22(10): 1859-1866.

Karabay NU, Oguz MG, 2005. Cytogenetic and genotoxic effects of the insecticides, imidacloprid and methamidophos. Genetic Molecular Research, 4(4): 653-662.

Karaca C, Sahin ME, Turabi MS, Dursun N, Altunoglu CC, Bedir C, Akyazi H, Keles R, Bahce UU, Ozer O, Algan N, Ocalan, Karatas GP, 2009. According to drug recommendations, Plant Protection Products, T. C. Ministry of Agriculture and Rural Affairs, General Directorate of Protection and Control, System Offset, Ankara, Turkey, 238-239p.

Klaric MŠ, Rumora L, Ljubanović D, Pepeljnjak S, 2008. Cytotoxicity and apoptosis induced by fumonisin $\mathrm{B} 1$, beauvericin and ochratoxin A in porcine kidney PK15 cells: effects of individual and combined treatment. Archives of Toxicology, 82(4): 247255.

Kocaman AY, Topaktas M, 2007. In Vitro evaluation of the genotoxicity of acetamiprid in human peripheral blood lymphocytes. Environmental and Molecular Mutagenesis, 48: 483-490. 
Kocaman AY, Topaktas M, 2010. Genotoxic Effects of a Particular Mixture of Acetamiprid and a-Cypermethrin on Chromosome Aberration, Sister Chromatid Exchange, and Micronucleus Formation in Human Peripheral Blood Lymphocytes. Environmental Toxicology, 2: 157-168.

Kocaman AY, Rencuzogullari E, Topaktas M, 2012. In vitro investigation of the genotoxic and cytotoxic effects of thiacloprid in cultured human peripheral blood lymphocytes. Environmental Toxicology, 29(6): 631- 641.

Kumar S, 2010. Effect of 2, 4-D and isoproturon on chromosomal disturbances during mitotic division in root tip cells of Triticum aestivum L. Cytology and Genetics, 44(2): 79-87.

Lages N, Balcão V, Nunes B, 2009. Risk assessment of human consumption of potentially contaminated red swamp crayfish (Procambarus clarkia): a conceptual approach. Rev. Faculdade de Ciencias da Saude, 6: 332-342.

Lander F, Knudsen LE, Gamborg MO, Järventaus H, Norppa H, 2000. Chromosome aberrations in pesticide-exposed greenhouse workers. Scandinavian Journal of Work, Environment \& Health, 26: $436-442$

Lee WJ, Cha ES, Park J, Ko Y, Kim HJ, Kim J, 2012. Incidence of acute occupational pesticide poisoning among male farmers in South Korea. American Journal of Industrial Medicine, 55(9): 799-807.

Marinovich M, Ghilardi F, Galli CL, 1996. Effect of pesticide mixtures on in vitro nervous cells: comparison with single pesticides. Toxicology, 108(3): 201-206.

Meisner LF, Belluck DA, Roloff BD, 1992. Cytogenetic effects of alachlor and/or atrazine in vivo and in vitro. Environmental and Molecular Mutagenesis, 19(1): 77-82.

Muranli FDG, Güner U, 2011. Induction of micronuclei and nuclear abnormalities in erythrocytes of mosquito fish (Gambusia affinis) following exposure to the pyrethroid insecticide lambdacyhalothrin. Mutation Research, 726(2): 104-108.

Muranli FDG, Rasgele PG, Kekecoglu M, Kanev M, Ozdemir K, 2015. Potential Genotoxicity of Acetamiprid and Propineb Singly or in Combination in Cultured Human Peripheral Blood Lymphocytes By Using MN Assay. Fresenius Environmental Bulletin, 24: 3947-3955.

Pandey RM, 2008. Cytotoxic effects of pesticides in somatic cells of Vicia faba L. Cytology and Genetics, 42(6): 373-377.

Pasquini R, Scassellati-Sforzolini G, Angeli G, Fatigoni C, Monarca S, Beneventi L, Bauleo FA, 1996. Cytogenetic biomonitoring of pesticide-exposed farmers in central Italy. J Environ Pathol Toxicol Oncol., 15(1): 29-39.

Pastor S, Gutiérrez S, Creus A, Xamena N, Piperakis S, Marcos R, 2001. Cytogenetic analysis of Greek farmers using the micronucleus assay in peripheral lymphocytes and buccal cells. Mutagenesis, 16(6): 539-545.

Pazy-Miño C, Bustamante G, Sánchez ME, Leone PE, 2002. Cytogenetic monitoring in a population occupationally exposed to pesticides in Ecuador. Environmental Health Perspectives, 110(11): 1077-1080.

Piatti E, Marabini L, Chiesara E, 1994. Increase of micronucleus frequency in cultured rat hepatocytes treated in vitro with benomyl and pirimiphos-methyl separately and in mixture. Mutation Research Letters, 324(1): 59-64.

Rasgele PG, Kaymak F, 2006. The cytogenetic effects of logran on bone marrow cells of Mus musculus. Pakistan Journal of Biological Science, 9: 2781-2786.
Rasgele PG, Muranli FDG, Kekecoglu M, 2014. Assessment of the Genotoxicity of Propineb in Mice Bone Marrow Cells Using Micronucleus Assay. Cytology and Genetics, 48(4): 233-237.

Rath NC, Rasaputra KS, Liyanage R, Huff GR, Huff WE, 2011. Dithiocarbamate toxicity-An appraisal. Pesticides in the Modern World-Effects of Pesticides Exposure, ed. M. Stoytcheva, InTech Publishing Online. New York, 323-340p.

Reffstrup TK, Larsen JC, Meyer O, 2010. Risk assessment of mixtures of pesticides. Current approaches and future strategies. Regulatory Toxicology and Pharmacology, 56(2): 174-192.

Rolandi A, De Marinis E, De Caterina M, 1984. Dithiocarbamate pesticides: Activity of Propineb in the micronucleus test in mice. Mutation Research, 135: 193- 197.

Roloff BD, Belluck D, Belluck A, Meisner LF, 1992. Cytogenetic studies of herbicide interactions in vitro and in vivo using atrazine and linuron. Archives of Environmental Contamination and Toxicology, 22(3): 267-271.

Shaik AS, Shaik AP, Jamil K, Alsaee AH, 2016. Evaluation of cytotoxicity and genotoxicity of pesticide mixtures on lymphocytes. Toxicology Mechanisms and Methods, 1-7.

Sato S, Tomita I, 2001. Short term screening method for the prediction of carcinogenicity of chemical substances: current status and problems of an in vivo rodent micronucleus assay. Journal of Health Sciences, 47(1): 1-8.

Schmid W, 1975. The micronucleus test. Mutation Research, 31: 9-15.

Schnug L, Leinaas HP, Jensen J, 2014. Synergistic sub-lethal effects of a biocide mixture on the springtail Folsomia fimetaria. Environmental Pollution, 186: 158-164.

Shaham J, Kaufman Z, Gurvich R, Levi Z, 2001. Frequency of sisterchromatid exchange among greenhouse farmers exposed to pesticides. Mutation Research, 491(1): 71-80.

Soloneski S, Reigosa MA, Larramendy ML, 2003. Effect of the dithiocarbamate pesticide zineb and its commercial formulation, the azzurro: V. Abnormalities induced in the spindle apparatus of transformed and non-transformed mammalian cell lines. Mutation Research., 536(1): 121-129.

Srivastava AK, Ali W, Singh R, Bhui K, Tyagi S, Al-Khedhairy AA, Shukla Y, 2012. Mancozeb-induced genotoxicity and apoptosis in cultured human lymphocytes. Life Sciences, 90(21): 815-824.

Sekeroglu V, Sekeroglu ZA, Kefelioglu H, 2013. Cytogenetic effects of commercial formulations of deltamethrin and/or thiacloprid on Wistar rat bone marrow cells. Environmental Toxicology, 28(9): 524-531.

Taillebois E, Thany SH, 2016. The Differential Effect of Low-Dose Mixtures of Four Pesticides on the Pea Aphid Acyrthosiphon pisum. Insects, 53: 1-7.

Tomizawa M, Yamamoto I, 1993. Structure-activity relationships of nicotinoids and imidacloprid analogs. Nihon Noyaku Gakkaishi (J. Pestic. Sci.), 18: 91-98.

Yao X, Min H, Lv Z, 2006. Response of superoxide dismutase, catalase, and ATPase activity in bacteria exposed to acetamiprid. Biomedical and Environmental Sciences, 19(4): 309-314.

Watson M, 1993. Propineb Pesticide residues in food: 1993 evaluations Part II Toxicology. IPCS Inchem Home, http://www.inchem.org/ documents/jmpr/jmpmono/v93pr16.htm (Erişim tarihi: 04 Nisan, 2016).

Zhang WJ, Jiang FB, Ou JF, 2011. Global pesticide consumption and pollution: with China as a focus. Proceedings of the International Academy of Ecology and Environmental Sciences, 1(2):125-144. 